\title{
RUSSIA'S ENERGY EXPANSIONISM ON THE EXAMPLE OF NORD STREAM 2 IN THE EUROPEAN UNION
}

\author{
Kristine Macharashvili, \\ Associate Professor, \\ Georgian National University SEU \\ Gocha Mikautadze, \\ Student, \\ Tbilisi State University
}

\begin{abstract}
The modern world depends on energy, the consumption of which is increasing, while the use of resources is becoming more and more intensive. It should be noted that imperialist Russia makes excellent use of this opportunity, which is reflected in the expansion and strengthening of its sphere of political influence. As we know, all states hold energy policies based on national-strategic values and define national aspirations and priorities. Russia has a big amount of energy resources, which it uses quite purposefully. The main tool of the Kremlin's expansionist policy is energy policy, which opposes European integration and increases its own role in the international arena. Despite the fundamental radical differences between the democratic West and undemocratic Russia, they still manage to find common preventive-cooperative relations in terms of energy policy. A clear example of this is the energy relations between Russia and Germany, which are complex and perennial.

The Nord Stream 2 is a project of global importance that explicitly increases the EU's energy dependence on Russia, which may not prove as beneficial to the Brussels side as it may do to the Moscow side. Both Putin and his governance system are using their country's resources and geopolitics "dishonestly" to exercise considerable influence on political space around them, serving the national interests of Russia. Therefore, in the eyes of the developed West, Russia is perceived as an aggressor and an undemocratic country, which creates a negative political landscape for both the European Union and the international political arena. That is why such maneuvering of Russia is not positively understood by any of the powerful states of the world, as this very project is found to be an integral part of world politics. The United States also supports this view. The Nord Stream 2, followed by Brexit, is the first international project and it is literally a dynamic action on how the energy relations between the EU and Russia can be continued. At the current stage, Germany's political actions are more profitable and productive for Russia than for the EU, since this case carries the potential for the energy sector of the two parties to become more integrated. ${ }^{1}$
\end{abstract} ${ }^{1}$ K.O. Lang, K. Westphal, „Nord Stream 2 - A Political and Economic Contextualisation“, Stiftung Wissenschaft und Politik, 2017
March, Available: https://www.swp-berlin.org/fileadmin/contents/products/research_papers/2017RP03_lng_wep.pdf [17.03.2021]. 
Keywords: European Union, Russia, Nord Stream 2, Energy Policy, Germany, Energy Expansionism.

\section{Introduction}

The 21st century has made it clear that much of the developed or developing world is dependent on energy. The topic becomes more pressing as soon as it concerns the relations between Russia and Germany in terms of energy sector cooperation. Energy is one of the most important emerging and functional sectors in the modern world, so every state strives to diversify its energy markets in order to take their energy security to a higher level.

Russia, one of the world's most powerful nations, has used its energy sector to pursue its national policies, which are unacceptable to the democratic world and not positively perceived in terms of the politicaleconomic spectrum. The Nord Stream 2 project is one of the biggest manifestations of the deepening of energy relations between Russia and the European Union. Through this project, they are bound to become more interdependent in the future, regardless the fact that the Kremlin's strategic political postulate is to increase its energy exports to the EU member states. That is why the EU has recently been compelled to pursue a coherent anti-policy so that Russia cannot "abuse" energy exports.

The study of the energy relations between Russia and the European Union in the modern international political arena is crucial, as it determines the future friendly and national security system between the states in the international political arena. There are radically different opinions about this project. Some of the public believes that Germany should suspend its participation in the project, and this is due to the "political distrust" running through the history of Russian-German relations, while the proponents of the project, however, believe that Nord Stream 2 will bring more economic benefits to the country than political damage. ${ }^{2}$

\section{Methodology}

The aim of the research is to determine the prospects and consequences of political-economic influence in energy sector between Russia and the European Union for the European side, as energy is one of the main sectors of the modern world, taking geopolitical or geostrategic importance in the international political arena. Upon the urgency of the topic, the following research questions arise: 1 . How does Russia's energy policy affect the European Union? 2. How does Russia use its energy resources for politicaleconomic dominance?

While working on the topic qualitative-empirical research methodology is applied, in particular the case study method, based on our project of Nord Stream 2 discussed in the political and economic context. Secondary literature, in particular, foreign language articles and scientific papers, is discussed in depth for

\footnotetext{
${ }^{2}$ R. Korteweg, „Energy as a tool of foreign policy of authoritarian states, in particular Russia “, European Union, 2018 April 27, Available: https://www.europarl.europa.eu/RegData/etudes/STUD/2018/603868/EXPO_STU(2018)603868_EN.pdf [17.03.2021].
} 
the comprehensiveness of the research topic. This research allows us to identify the main mechanisms characteristic of Russia's energy expansionism and to predict what challenges the EU may face. The research increases the public awareness of the issue, as the Georgian society suffers from a shortage of scientific material in this regard. The latter, some extent, damages the country's European integration process.

\section{Russia's Geopolitical and Strategic Intentions in Energy Sector in the Modern Time Period}

Russia's geopolitics is quite complex, while international relations are biased and have been reconstructed over the centuries. Since R. Kjellen, the Swedish scientist and politician, first used the term geopolitics in the 1910s, and further elaborated by the German scientist K. Haushofer, it has established itself as part of the practical philosophy of German nationalism from the second half of the same century. Despite its philosophical and political aspects, in the case of Russia, geopolitics is an ideal means of fulfilling its expansionist intentions. The ways in which foreign policy is carried out between states have changed over the centuries, the energy expansionism being one such example used by the Kremlin to pursue its strategic goals. However, Russia faces another strongest political-economic union, the European Union, also demonstrating great interest in energy resources. The European Union is using so-called "forced diplomacy" against Russia, sending Russia to feel non-dominant in the geopolitical spectrum. Consequently, Russia retaliates to gain a foothold in the world political-economic market, echoing in the devaluation of energy prices. ${ }^{3}$

In modern times, Russia's economic struggle for expansion is manifested through the form of a new project of Nord Stream 2. With the so-called "friendly format", Russia, using its energy resources, is trying to subjugate European countries, Germany in particular. About 25\% of Germany's energy consumption involves natural gas: Russia, Norway and the Netherlands being the largest importers of it. Russia links to Germany by the two existing gas pipelines: the Yamal-European gas pipeline (32.9 billion m3) and the Nord Stream (55 billion m3). ${ }_{4}^{4}$ Following the launch of the Nord Stream 2, the direct export of gas from Russia to Germany will increase twofold, so that Germany will no longer have to provide certain benefits to the transit countries, significantly reducing the expenses. The capacity of the Nord Stream 2 will be similar to that of Stream 1 ( 55 billion m3)..$^{5}$ It should also be noted that about $40 \%$ of gas imported to Europe comes from Russia. Through attaching a less functional status to the Yamal-Europe gas pipeline, Russia deliberately and strategically tries to increase the energy dependence of both Germany and Europe. If Russia can really do that, it is possible that other EU countries, such as the Visegrad countries, ${ }^{6}{ }^{7}$ will

\footnotetext{
${ }^{3}$ A. Goldthau, ,Assessing Nord Stream 2: regulation, geopolitics \& energy security in the EU, Central Eastern Europe \& the UK”, EUCERS, 2016 July, Available:

4 J. Wettengel, "Germany's energy consumption and power mix in charts", CLEW, December 21, 2020, available at: https://www.cleanenergywire.org/factsheets/germanys-energy-consumption-and-power-mix-charts. [L. s. 17.03.2021].

5,GAZPROM “Official Web Page, „Germany-The biggest foreign buyer of Russian gas “, GAZPROM, Available at: https://www.gazprom.com/projects/germany/ [L. s.17.03.2021].

${ }^{6}$ See Footnote 4.

${ }^{7}$ J. Wettengel, „Gas pipeline Nord Stream 2 links Germany to Russia, but splits Europe “, CLEW, 2021 February 19, Available: https://www.cleanenergywire.org/factsheets/gas-pipeline-nord-stream-2-links-germany-russia-splits-europe [L.s.17.03.2021].
} 
find themselves in a similar political-economic cheap trap. If it ever comes true, it can be said that the EU will lose this strategic battle with Russia. If we ever consider the Nord Stream 2 as a political entity, Russia's expansionist intentions will become clearer, as solidified by one of Ratzel's seven expansion laws: "the state expands by absorbing small political entities". ${ }^{8}$ The idea of the economic project "Nord Stream 2" is an excellent means of energy expansion, which appeared in the country's leadership in 2018. ${ }^{9}$ The dominant countries in this project are Russia and Germany. The Nord Stream 2, like the Nord Stream 1, is 1,230 kilometers long and supplies gas directly from Russia for export to Germany via the Baltic Sea. Due to similar structure and route, the gas pipelines are sometimes called the "twin gas pipeline". The underwater pipeline from the east of Russia joins the German coast, through the waters of Sweden, along the Baltic Sea, Finland and Denmark. Manufacturing the materials needed for the project began in Germany in 2016, and later in September 2018, for the first time, they were phased into construction. It should be noted that the construction of the Nord Stream 2 is not completed and is still underway. The project is estimated at $\$ 11$ billion, $50 \%$ of which is paid by the Russian company Gazprom, being the sole shareholder, while $50 \%$ of the project is funded by European companies, including Wintershall and Uniper (German), Royal Dutch Shell (Netherlands), Engie (France) and OMV (Austria). As it is clearly seen, Russia and Germany share the common interests, while some EU member states and the United States remain opposed to deepening the relations between Russia and EU to avoid potential Russian energy dominance in international arena. ${ }^{10}$

\section{How does Russia use energy resources for political dominance}

The importance of Russia's geopolitical and strategic location and the territory rich in energy resources are driving its imperialist aspirations, leading to the formation of its foreign policy. Russia is one of the important actors in the world political arena, which plays the role of a regulatory state; consequently, powerful countries such as Germany, France, England have often made political and economic concessions throughout the history. Finally, a seemingly accountable Russian power in this format of concessions maintains a dominant position in the hierarchy of prestige. And yet, what is the political-economic and geostrategic significance of Russia in the modern times? Does it still have the strength of the past or it is closing the reins in its hands? It is a country that will always be able to maintain its strategic dominance, as it will resort to any format of expansive, diplomatic or military action against the states or organizations that will block it in the political arena. Russia identifies the EU as one of its opponents, and in modern times its next ideology is to introduce a political-economic imbalance in the union with the energy it uses as a means of manipulating the geostrategic economy. This is not an easy political path to take, as the EU is backed by the world's most powerful state, the United States. The latter's political position is also clearly reflected through the attitude towards the Nord Stream 2 developer and the sanctions imposed on the

\footnotetext{
${ }^{8}$ N. Chitadze, "Geopolitics", Universal Publishing House, 2011. p. 113

${ }^{9}$ GAZPROM's official website, Germany-The biggest foreign buyer of Russian gas, GAZPROM, available at: https://www.gazprom.com/projects/germany/ [L. s. 17.03.2021].

${ }^{10}$ A. Alania, „German-Russian Relations Examination on Case Study of "Nord Stream 2" Project”, Journal of Young Researchers, 2017 July, Available: http://jyr.tsu.ge/index.php/Hoome/ebaut/ge/2/5 [L. s.17.03.2021].
} 
Russian Federation, as the Nord Stream 2 project is one of the biggest niches in Russian energy expansion policy. ${ }^{11}$ Germany's aspiration is a manifestation of the country's national interests; it is forced to receive "cheap gas" from the Russian Federation despite "tough" experiences in energy relations with this country. This includes the fact that gas supplies to Ukraine were cut off in 2009, leading to a 13-day power outage during the winter, which led to a 13-day energy collapse for $16 \mathrm{EU}$ member states. ${ }^{12}$ Low-priced gas supplied by the Kremlin is acceptable to Europe, projected to further strengthen Russia's economic and energy dominance and its leverage in the international arena. If successful, Russia, without any military confrontation, will be able to regain a superpower status through its energy resources and "commercial diplomacy", which will accelerate the process of realization of its expansionist aspirations. ${ }^{13}$

\section{Conclusion}

In the modern world, the importance of energy is at an all-time high. Developed and developing countries are trying to diversify energy markets and Germany is no exception. The case is interesting in that Germany is deepening energy cooperation with the Kremlin, which has historically been its sworn enemy several times. Russia's political intentions are known to the world, which is reflected in its foreign policy. North Stream 2 is a real manifestation of the targeted politicization of its own energy resources by Russia in order to make Europe more dependent on it. For their part, this process is perfectly perceived by the United States and certain European Union states, which express their attitude through imposing political and economic sanctions. Nevertheless, Russia manages to impress some of the EU's largest driving powers, such as Germany and France, with certain degree of "goodness". The North Stream 2 definitely increases the scale of Russia's influence in the European Union, which in some ways threatens the stability of the democratic world. That is why it is necessary to find forms of economic cooperation that will not be biased and will not harm European integration. It is important for the EU and individual states to take into account the foreign policy course, practices, intentions and aspirations of their partner countries.

\footnotetext{
${ }^{11}$ D. Elijah, „TOPIC PAGE: Nord Stream 2“, ICIS, 2021 March 5, https://www.icis.com/explore/resources/news/2020/11/20/10463483/topic-page-nord-stream2\#: : text=Nord\%20Stream\%202\%20to\%20launch,Angela\%20Merkel\%20on\%2011\%20January [L. s. 17.03.2021].

12 The official website of NBC News, "Europeans shiver as Russia cuts gas ships", NBC News, January 6, 2009, available at: https://www.nbcnews.com/id/wbna28515983 [L. s. 17.03.2021].

${ }^{13}$ Ibid.
} 


\section{Bibliography}

1. Kai-Olaf Lang, Kirsten Westphal, „Nord Stream 2 - A Political and Economic Contextualization “, Stiftung Wissenschaft und Politik, 2017 March, Available: https://www.swpberlin.org/fileadmin/contents/products/research_papers/2017RP03_lng_wep.pdf [Last seen 17.03.2021].

2. Rem Korteweg, „Energy as a tool of foreign policy of authoritarian states, in particular Russia “, European Union, 2018 April 27, Available: https://www.europarl.europa.eu/RegData/etudes/STUD/2018/603868/EXPO_STU(2018)603868_EN.pdf [Last seen 17.03.2021].

3. Diane Elijah, „TOPIC PAGE: Nord Stream 2“, ICIS, 2021 March 5, Available: https://www.icis.com/explore/resources/news/2020/11/20/10463483/topic-page-nord-stream2\#: :text=Nord\%20Stream\%202\%20to\%20launch,Angela\%20Merkel\%20on\%2011\%20January [Last seen 17.03.2021].

4. Julian Wettengel, „Gas pipeline Nord Stream 2 links Germany to Russia, but splits Europe “, CLEW, 2021 February 19, Available: https://www.cleanenergywire.org/factsheets/gas-pipeline-nord-stream-2links-germany-russia-splits-europe [Last seen 17.03.2021].

5. Ana Alania, „German-Russian Relations Examination on Case Study of “Nord Stream 2" Project”, Journal of Young Researchers, 2017 July, Available: http://jyr.tsu.ge/index.php/Hoome/ebaut/ge/2/5 [Last seen 17.03.2021].

6. „GAZPROM“ Official Web Page, „Germany-The biggest foreign buyer of Russian gas“, GAZPROM, Available: https://www.gazprom.com/projects/germany/ [Last seen 17.03.2021].

7. Julian Wettengel, „Germany's energy consumption and power mix in charts “, CLEW, 2020 December 21, Available: https://www.cleanenergywire.org/factsheets/germanys-energy-consumption-and-powermix-charts [Last seen 17.03.2021].

8. Andreas Goldthau, „Assessing Nord Stream 2: regulation, geopolitics \& energy security in the EU, Central Eastern Europe \& the UK”, EUCERS, 2016 July, Available:

https://www.asktheeu.org/en/request/7115/response/23365/attach/2/Goldthau\%20July\%202016.pdf [Last seen 17.03.2021].

9. "NBC News” Official Web Page, „Europeans shiver as Russia cuts gas shipments”, NBC News, 2009 January 6, Available: https://www.nbcnews.com/id/wbna28515983 [Last seen 17.03.2021].

10. Nika Chitadze, „Geopolitics “, Published by Universal, 2011. pg. 113. 
